\title{
MIT Graduate Networks: the early years
}

\author{
Pedro Garcia Duarte ${ }^{1}$
}

\begin{abstract}
RESUMO:
Após a Segunda Guerra Mundial os economistas adquiriram uma importância crescente na sociedade norte-americana, de modo geral. Neste período a produção de doutores em economia $(\mathrm{PhD})$ nos Estados Unidos aumentou substancialmente e se tornou uma indústria menos concentrada. Além disto, houve uma reformulação do ensino de pós-graduação em economia nos EUA que refletiu as mudanças fundamentais que a ciência econômica passava: a sua matematização, a dominância do neoclassicismo, os avanços da econometria, a chamada revolução keynesiana, e a americanização desta ciência. A centralidade adquirida pelo programa de pós-graduação em economia do MIT poucos anos depois de sua criação, em 1941, faz dele um caso de estudo interessante para entendermos as transformações da ciência econômica norte-americana. Meu objetivo neste artigo é explorar os anos iniciais do programa e sua consolidação, com foco nas décadas de 1940 e 1950.
\end{abstract}

Palavras-Chave: MIT, Paul Samuelson, Robert Solow, Doutorado em Economia

\begin{abstract}
:
After World War II economists acquired increasing importance in the American society in general. Moreover, the production of economics PhDs in the United States increased substantially and became a less concentrated industry. This period witnessed also the reformulation of the graduate education in economics in the US, informed by the several changes that were occurring in economics: its mathematization, the neoclassicism, the advancement of econometrics, the "Keynesian revolution", and the ultimate Americanization of economics. The centrality that the MIT graduate program acquired in the postwar period makes it an important case study of the transformation of American economics more generally. Therefore, my aim here is to scrutinize the formative years of this graduate program, mostly the 1940s and 1950s.
\end{abstract}

Keywords: MIT, Paul Samuelson, Robert Solow, Economics PhD

Área ANPEC: 01

Classificação JEL: B20, B00, A23

\footnotetext{
${ }^{1}$ Department of Economics, University of São Paulo, Brazil (pgduarte@usp.br). I thank participants of the HOPE 2013 Conference and of the seminar at Cedeplar (UFMG, Brazil) for comments on an earlier draft, and Nora Murphy, MIT Institute archivist, and William R. Massa Jr. and Nancy F. Lyon, Yale archivists, for their kind help with different institutional information. Financial support from $\mathrm{CNPq}$ (Brazil) is gratefully acknowledged.
} 


\section{MIT Graduate Networks: the early years}

After World War II economists acquired increasing importance in the American society in general, and not just as specialists advising the government, particularly after the Employment Act of 1946 that created the Council of Economic Advisers (Goodwin 1975, 6; Bowen 1953, iii) ${ }^{2}$. In this period, the production of economics $\mathrm{PhDs}$ in the United States changed from a highly concentrated industry (which nonetheless involved a high number of institutions) (Bowen 1953, 8) to a more competitive one, as argued by William J. Barber (1996).

No matter the changes in the degree of such competitiveness, there has been a general expansion of graduate education in economics in this period that accompanied that of education in general, after the GI Bill of 1944. This increase was carried both through expanding the size of existing graduate programs and through the creation of new, competing ones. The MIT $\mathrm{PhD}$ program in industrial economics was born in 1941 with the help of the newly hired Paul Samuelson, discontinued during the war (Cherrier, this volume), and then reenacted for a sizable expansion that transformed it in one of the most important programs in the US.

The increase in size of the economics graduate education is impressive and can be realized by looking at the number of PhDs awarded by American universities, as Howard R. Bowen (1953, 29) presented:

For example, since the end of World War II (academic years 1945-46 through 1951-52), about 1,800 Ph.D.'s have been awarded by American universities. The magnitude of this figure can be appreciated when it is realized that this post-war crop represents nearly one-third of all the doctorates in economics ever awarded in this country. In all the years prior to 1945-46 fewer than 4,000 doctorates had been granted.

The immediate postwar period witnessed not only a considerable expansion of economics graduate education, but also its reformulation. This occurred in a period when economics was going through important changes, informed by its mathematization (cf. Mirowski 2002, Weintraub 2002), by the stabilization of a neoclassical way of doing economics (Morgan and Rutherford 1998), by the advancement of econometrics and the "Keynesian revolution" (both stressed by Barber 1996), and by the ultimate Americanization of economics (see Weintraub, this volume). ${ }^{3}$ This period also witnessed the proliferation of different fields in economics and the rearrangement of their space in the graduate education.

Given all this, the changing economics graduate education in the US, with increasing emphasis on technical training, was part and parcel of the broader changing face of economics profession. The centrality that the MIT PhD program acquired in the postwar period makes it an important case study of the transformation of American economics more generally. Therefore, my aim here is to scrutinize the formative years of this program, mostly the 1940s and 1950s. I shall look at the student and faculty bodies, advisors and advisees and their placement, and try to have a sense of the thesis and fields in order to better understand the distinctive features of the program and of its products.

\footnotetext{
${ }^{2}$ See Fourcade (2009, ch. 2) for a broader context of the professionalization of American economics and "its close connection to [the field of] business" (69).

${ }^{3}$ The Keynesian factor was very present in Samuelson's attempt to write his textbook, Economics. It was understood to be a MIT product with unacceptable Keynesian ideas by Samuelson's critics, the very same ideas criticized with respect to Lorie Tarshis' textbook, as discussed by Yann Giraud (this volume).
} 


\section{1 - Economics Faculty and Major Advisors}

The department of economics and social science at MIT was relatively small in the early 1940s and, due also to its newly created $\mathrm{PhD}$ program in industrial economics, had professors with different backgrounds. ${ }^{4}$ From 1945 to 1947 the department offered an additional PhD program, in group psychology. Thus when we look at the seventeen regular professors (including all levels) at the department in 1945, for instance, we see that six of them were professors of economics, five were professors of psychology, three were professors of industrial relations, and the others were professors of international relations, human relations, and statistics. Ten years later, in 1955, the relative number of economists was roughly the same, but the department had an even higher variety of professors: there were nine professors of economics out of the twenty six regular professors of the department, five professors of psychology (counting here two that were professors of social psychology) - a much smaller ratio than in 1945 -, three of industrial relations, and several others: statistics (two), political science (five), sociology (one), and history (one). ${ }^{5}$ The appearance of political scientists is explained by the introduction, in 1955, of political science at MIT under the economics department. ${ }^{6}$ Once again, in the 1950s the doctoral degree in industrial economics was not the only one offered by the department: from 1958 to 1965 there was also a $\mathrm{PhD}$ program in political science offered by the department of economics.

Another interesting fact about the department in the early years is that there were just two chairmanships from 1944 to 1960: that of Ralph Evans Freeman (1933-1958) and of Robert L. Bishop (1958-1964). ${ }^{7}$ The MIT economics faculty that had 13 members (including all ranks, assistant, associate and full professor) in 1944 became 30 in the year Freeman stepped down, and reached 36 in 1959 under Bishop. The department hired professors from major producers of $\mathrm{PhDs}$ in the postwar years, such as Harvard, Columbia, and Chicago. The ties with Harvard were particularly strong, as we shall explore when looking at major MIT advisors.

The evidence on the size of the faculty body should be complemented by another aspect of the MIT economics department at this time: the use of associates to teach courses and aid with research. As shown in Figure 1, in the 1940s the faculty was small but there were a great number of associates. Over time, the faculty increased and research assistants and associates decreased, vanishing by the mid-1950s. The number of instructors was somewhat stable, with a reduction by the late 1950s.

\section{INSERT FIGURE 1 HERE}

It was not very often to see someone transitioning from one of the associate positions to another. Thus, it is not the case that the reduction in the number of research assistants and associates is equivalent to the increase in the number of instructors. But a more significant and frequent transition was from instructor to assistant professor: this was the case of important MIT professors such as Robert L. Bishop, Alex Bavelas, James E. Boyce, and George B. Baldwin. Nonetheless, the scale of this transition does not account fully for the expansion of the number of regular professors. Besides this, it is worth noting that

\footnotetext{
${ }^{4}$ In 1934 the department, which was then "Department of Economics and Statistics", became the "Department of Economics and Social Science". Only in 1965 it became the "Department of Economics". For simplicity I shall not make these distinctions here and just refer to it as the department of economics.

${ }^{5}$ This information comes from the Massachusetts Institute of Technology Bulletin (course catalogues) for each of the years mentioned, available online at: http://dome.mit.edu/handle/1721.3/81660 (accessed on January 15th, 2013).

${ }^{6}$ Political science at MIT grew out of the Center for International Studies (CIS) and was part of the attempt to include social sciences in the engineering and science curricula. It became an independent department only in 1965 (http://web.mit.edu/polisci/about/history/index.html; accessed on February 25, 2013). See Beatrice Cherrier (this volume) for a discussion of the CIS.

${ }^{7}$ Bishop had Edgar Cary Brown as his successor, who in turn had another long chairmanship, from 1964 to 1982 (though not as long as Freeman's).
} 
visiting professors in this period started arriving at MIT in 1953 and became very numerous in the second half of the 1950s, reaching the peak of eight in 1956 and 1957 (more than thirty percent of the number of regular professors in the department in these years). Most of the visitors in the 1950s were economics professors, and included people like Paul Rosenstein Rodan (visitor from 1954 to 1959, when my sample finishes); Wilfred Malenbaum, Everett E. Hagen and Benjamin H. Higgins (1954-58); Frank Hahn and Evsey D. Domar (1956); Hendrik S. Houthakker (1957); and Robert H. Strotz (1958), among others.

The size of the economics department may perhaps be a weak indicator of the size of the $\mathrm{PhD}$ program and its networks. Let us then look at the advisors' side, based on a dataset of all theses defended at the department of economics at MIT from 1944 to 2009, focusing on the early years. ${ }^{8}$ As I shall show later, the number of economics PhDs from MIT increased steeply from the 1940s to the 1970s. In order to have a sense of the major advisors in each decade, we can look at the percentage of graduated $\mathrm{PhDs}$ advised by each professor in each decade, as recorded in Figure 2. ${ }^{9}$

\section{INSERT FIGURE 2 HERE}

In the 1940s, three professors advised (or co-advised) eighty percent of the fifteen PhDs who graduated from 1944 to 1949: Douglass V. Brown (Harvard PhD, 1932), Charles A. Myers (Chicago $\mathrm{PhD}, 1939$ ), and Paul A. Samuelson (Harvard PhD, 1941), with the first two working on industrial relations. Samuelson advised Lawrence Klein, the first economics PhD from MIT in 1944. So the PhD program was indeed small and concentrated on few advisors. Other advisors at the MIT economics department at the time include Dorwin P. Cartwright (Harvard PhD in psychology, 1940), professor of psychology and a leading figure in social psychology. ${ }^{10}$ One of Cartwright's economics students in this period was Harold Harding Kelley, who became an important psychologist later on.

In the following years new advisors entered the scene and a process of strengthening the economics identity of the department started, eventually leading to the migration of the industrial relations group to the Sloan School of Management. In addition to the three major advisors of the 1940s five new names advised a significant percentage of the ninety two PhDs who graduated in the 1950s: Charles P. Kindleberger (Columbia PhD, 1937), Morris A. Adelman (Harvard PhD, 1948), Robert M. Solow (Harvard PhD, 1951), Robert L. Bishop (Harvard PhD, 1949), and E. Cary Brown (Harvard PhD, 1948). Altogether these eight professors advised roughly seventy five percent of the PhDs who graduated from the economics department in the 1950s. There are other important advisors displayed in Figure 2: Evsey Domar (Harvard PhD, 1947), hired at MIT in 1958, and Edwin Kuh who was another Harvard PhD (1955) hired at MIT in 1959.

With new professors being hired in the subsequent decades, we can see in Figure 2 the life-cycle of an advisor, which generally shows a slow reduction in the percentage of students advised over time, when it is not the case that they leave MIT to another job and cease to advise students there. Typically, as we see in Figure 2, advisors are active for roughly three decades, advising a decreasing share of graduate students over time. This is the case of Douglass Brown, Charles Myers, and Paul Samuelson, for instance. But the life-cycle of Robert Solow is different and noteworthy: he had his first PhD student graduating in 1954 and the last advisee finishing in 1997, with a substantial increase in the share of

\footnotetext{
${ }^{8}$ I am most grateful to Roger Backhouse for kindly sharing his dataset (obtained from MIT) with me. It was complemented with a search at the theses section of the MIT Barton online catalog and with additional data on students' placements.

${ }^{9}$ In this Figure and in the following I included as one advisee a student who had a given professor as one of his advisors. So, in case of a student who was advised by two professors he enters as one student for each of them. But I do not include the other readers or members of the thesis committee in this data.

${ }^{10}$ Cartwright was a co-founder, with Kurt Lewin, of the MIT Research Center for Group Dynamics (RCGD), where most of his students developed their work. This Center moved to the University of Michigan in 1948, a year after Lewin's death, allegedly due to funding difficulties (http://www.rcgd.isr.umich.edu/history/, accessed on January 10 ${ }^{\text {th }}, 2013$ ).
} 
students advised during his first decade at MIT. Solow was instrumental in changing over time the direction of scholarship in the PhD program towards economics and away from management and industrial relations.

Given that the life-cycle of the first generations of MIT advisors is related to the hiring of new professors, it is worth to have a look on the generation of advisors that arrived at MIT in the 1960s, as Figure 3 shows. There is an interesting aspect of this generation: that it includes names of professors that also became intimately associated with the image of the economics department, some of whom graduated from MIT.

INSERT FIGURE 3 HERE

We can see that the major advisor of the 1960s, Franklin Fisher, advised a percentage of graduate students still inferior to that of professors of earlier generations, such as Robert Solow, Charles Kindleberger, and Morris Adelman. This generation had, once again, ties with Harvard: Franklin Fisher (1960), Michael Piore (1966), and Lance Taylor (1968) all obtained their PhDs there. Other major advisors arriving in the 1960s included Jerome Rothenberg (Columbia PhD, 1954), Franco Modigliani (New School PhD, 1944), and a series of MIT PhDs: Peter Diamond (PhD 1963), Peter Temin (PhD 1964), and Jagdish Bhagwati (PhD 1967), with the last two having MIT as their first placement after graduating (either the economics department, in the case of Bhagwati, or the business school, in the case of Temin).

The department of economics at MIT used to hire some of its own students. The first such occurrence in the period of the 1940s and 1950s was George P. Shultz, a student of Douglass Brown who graduated in 1949 and did not advise graduate students at MIT. But more interesting to the issue of graduate networks is to look at MIT PhDs who became advisors in the economics department for some part of their careers. These are the second level of a graduate network: a professor who graduated from MIT and advised students there. Here we have Herbert A. Shepard, P. Diamond, P. Temin, J. Bhagwati, and Stanley Fischer. ${ }^{11}$ Table 1 then reports the number of students advised by decade by a selection of major MIT advisors, some who obtained their $\mathrm{PhD}$ elsewhere and others who graduated from MIT. ${ }^{12} \mathrm{In}$ the second column we find the year when advisors obtained their PhDs and either the university from which they graduated (in the case of those with a $\mathrm{PhD}$ from other institutions) or their advisors (for the MIT students).

\footnotetext{
${ }^{11}$ See Svorencik (this volume) for family trees of MIT advisers who graduated from MIT, as well as other data on faculty and students, for the entire period 1944-2011.

12 The data in this table, as in Figures 1 and 2, includes students' advisors and co-advisors.
} 
Table 1

MIT Advisors

Number of MIT Advisees

\begin{tabular}{|c|c|c|c|c|c|c|}
\hline Graduated elsewhere & University and Year & 1944-49 & 1950-59 & 1960-69 & 1970-79 & 1944-2009 \\
\hline D. Brown & (Harvard, 1932) & 5 & 11 & 2 & 0 & 18 \\
\hline C. Kindleberger & (Columbia, 1937) & 0 & 13 & 25 & 10 & 49 \\
\hline C. Myers & (Chicago, 1939) & 3 & 17 & 12 & 1 & 34 \\
\hline P. Samuelson & (Harvard, 1941) & 4 & 10 & 4 & 8 & 26 \\
\hline M. Adelman & (Harvard, 1948) & 0 & 8 & 16 & 10 & 35 \\
\hline R. Solow & (Harvard, 1951) & - & 7 & 29 & 25 & 77 \\
\hline F. Fisher & (Harvard, 1960) & - & - & 13 & 25 & 54 \\
\hline Graduated from MIT & $\begin{array}{l}\text { Advisor's Advisor } \\
\text { and Year }\end{array}$ & & & & & \\
\hline H. Shepard * & (A. Bavelas, 1950) & - & 6 & 0 & 0 & 6 \\
\hline P. Diamond & (R. Solow, 1963) & - & - & 0 & 8 & 41 \\
\hline P. Temin * & (C. Kindleberger, 1964) & - & - & 0 & 10 & 20 \\
\hline J. Bhagwati * & (C. Kindleberger, 1967) & - & - & 0 & 10 & 12 \\
\hline S. Fischer & (F. Fisher, 1969) & - & - & 0 & 13 & 52 \\
\hline
\end{tabular}

* First placement after graduating was at MIT

Three things stand out in Table 1. The first, already noticed before, is that several MIT advisors graduated from Harvard, which was the leading producer of economics $\mathrm{PhDs}$ at the time (cf. Bowen 1953, 209-10; Barber 1996, 18). The second is that if we identify both the number of students directly advised by a particular professor and those advised by someone who was his student as one important aspect of the influence of that professor in the graduate program, it seems fair to state that Charles Kindleberger was very important. Not only he advised a significant amount of students over time (with the highest share of the student body in a given decade he advised was a little below fifteen percent, as shown in Figure 2), but he was also the advisor of two professors who became major advisors at MIT, Peter Temin and Jagdish Bhagwati, who later on advised a significant amount of MIT students. Robert Solow and Franklin Fisher come after Kindleberger in this dimension: both advised a great number of students and each one had a prominent student becoming an important advisor at MIT, Peter Diamond and Stanley Fischer, respectively. Finally, Samuelson advised a relatively small number of students when compared to other professors such as Solow, Fisher, Fischer, Kindleberger and Diamond, which certainly does not decrease his importance as a teacher, academic interlocutor and magnet for students and visitors going to MIT (as praised by some of his prominent students; cf. Dixit 2012, 23-4, and Szenberg et al. 2005, 24-26, 99-108).

Given that we identified the major advisors, it is interesting to have an idea of their main lines of research. To this end, I looked not at their publications but rather at the thesis of their advisees to have a sense of the kinds of works they supported. Through the theses' titles and fields to which their students were affiliated immediately after graduating, and using the list of the fields of specialization in economics, I tried to identify broad lines of research associated with MIT advisors. ${ }^{13}$

What we see is that there were several of the main advisors who had a clear orientation toward industrial relations and business administration, with most of their advisees writing on these themes: Douglass Brown, Charles Myers, and Herbert Shepard. The first two were professors of industrial relations while Shepard was professor of sociology at the MIT economics department. The department also had Charles Kindleberger (a professor of economics) advising mostly on international economics, though also covering a few other areas such as income and employment theory, economic systems, economic growth, and monetary economics and business fluctuations. Then, Morris Adelman (professor of economics) supervised students working on themes of industrial organization. Finally, the department

\footnotetext{
${ }^{13}$ The information on fields in economics comes from the American Economic Association directory of members and handbooks from several years.
} 
had Paul Samuelson and Robert Solow who each advised a diverse set of works, including monetary and business fluctuations, price theory, public finance, international economics, investment and security markets (finance), mathematical methods and econometrics, and economic growth.

We can now go to the other side of the network, the students, and see not only the substantial increase in the size of the $\mathrm{PhD}$ program and the placement of these students, but also the important changes in the very conception of a PhD degree in the United States in the 1950s.

\section{2 - MIT PhD Students}

Despite the fact that economists in the US were a heterogeneous group with a lower prestige among the general public as compared to "other learned professions" (Bowen 1953, 33), they acquired increasing importance in the American society. ${ }^{14}$ This, combined with the "technicalization of economics" (Bowen 1953, 103), raised concerns with the form, standards, and nature of the graduate program in economics. A wide range of such issues was raised in the 1940s and 1950s: from the list of courses, going through the nature of the graduate work and of a $\mathrm{PhD}$ thesis, through the interinstitutional diversity among graduate programs in the US, the duration of a $\mathrm{PhD}$ program, and job prospects for an economist with a $\mathrm{PhD}$ degree, among others.

These issues and changes taking place in economics at the time motivated the American Economic Association to sponsor a study of the economics profession. Howard Bowen (at Williams College when the report was published) led a group of representatives from Carnegie Institute of Technology (G. L. Bach), University of Chicago (Milton Friedman), University of Michigan (I. L. Sharfman), and Duke University (J. J. Spengler). ${ }^{15}$ Their effort involved, in 1951-52, interviewing chairmen, professors and graduate students, and visiting several institutions, as well as compiling data on different graduate programs. This group produced a long study published in the American Economic Review in 1953 (Bowen 1953).

I want to highlight here two main issues from that report: first, the proposal for a core in the $\mathrm{PhD}$ training, and, second, a new understanding of the nature of the $\mathrm{PhD}$ thesis. With respect to the first, the view held at the time was that the economics undergraduates had very uneven backgrounds and no great intellectual independence and maturity when they entered graduate school (Bowen 1953, 3-4, 7). According to Bowen $(1953,40)$ this led to a widespread understanding that a graduate program should "require knowledge of fundamentals [(economic theory, economic history, history of ideas, and research techniques)] and breadth of understanding" from its students and emphasize scholarship: the idea that the graduate training is just one of a sequence of steps in their career(instead of being its pinnacle), and that they are just learning the rudiments of their profession that they will further develop when practicing it.

Bowen $(1953,42-54)$ then expressed his views on "the standards to be met by a Ph.D. candidate" (42) that would respect the diversity of interests, capacities, skills, and differences among universities that characterized economics back then. ${ }^{16}$ Among the several issues that were part of these standards

\footnotetext{
${ }^{14}$ See Fourcade (2009, 96-114) for an analysis of "the academic roots of public expertise" in the US.

${ }^{15}$ Bowen obtained his $\mathrm{PhD}$ from the University of Iowa in 1935 and was a professor of economics (and dean) at the University of Illinois from 1947 to 1952, when he moved to Williams College. At Illinois he became dean in 1947 with a mandate "to stimulate research and scholarship, to improve teaching, to bring curricula up to date" among other issues discussed by Solberg and Tomilson (1997). The authors show how Bowen was forced to resign as dean in 1950 after a harsh conflict (known as the Bowen controversy) initiated by reforms he implemented. This controversy, they argue, also reflected a clash between free-market ideologies and Keynesian ideas associated with Bowen and others. Just before resigning as a dean he was appointed as chair of the ad hoc committee that started working in 1951 after obtaining a Rockefeller Foundation grant to finance it (Bowen, 1953, iii).

${ }^{16}$ Bowen $(1953,41)$ considered that imposing a "uniform and detailed minimal standards" would neither be possible nor desirable in economics.
} 
there was the idea of a common core, coupled with the realization of comprehensive exams to test the students' proficiency, and with the organization of the graduate training in fields (major and minor fields) - when students would further acquire both breadth and specialization.

What should be the content of such common core to be required of all $\mathrm{PhD}$ students? Bowen (1953) sent questionnaires to professors, who agreed in general that this core should be required, and a "near-agreement" emerged on "only one subject, namely, economic theory" (104) - though the very understanding of what would be economic theory was not completely clear, as the author discussed (Bowen 1953, 106, 109-11). Other subjects that had strong support for inclusion in the core were statistics, economic history, history of economic thought, and monetary and banking theory (105-6).

Given that the economics training would proceed through a core of courses, comprehensive exams, and fields, and that economics was understood to have become more technical, it follows that graduate students were expected to demonstrate the mastering of techniques. Therefore, it is not surprising to see the desire to change the nature of a $\mathrm{PhD}$ thesis, which was already an integral part of the requirements of economics graduate programs. Thesis would still have to be "an important and original contribution to knowledge" (Bowen 1953, 153), but no longer they would "deal with problems that are too comprehensive", which used to imply in massive tomes with much of a synthesis of "other economists' ideas rather than reports of original research" (156). Students should instead research "a specific and limited problem" (157). Bowen $(1953,156)$ thus welcomed the tendency of having dissertations of article length provided it did not compromise its quality and "adequate documentation and description of methodology." After all, doctoral dissertations are not to be considered "the student's final creative effort" (157). ${ }^{17}$

Moreover, there was an important change in the social role of the $\mathrm{PhD}$ degree in the US. As Fourcade $(2009,77)$ puts it, this degree served "as a key instrument of both professional standardization vis-à-vis outside markets and disciplinary, intellectual standardization inside.” For Bowen (1953, 179), the $\mathrm{PhD}$ was no longer "a union card for college teaching" conferred after long gestation to older college teachers "seasoned by years of practical experience":

If, on the other hand, the Ph.D. is regarded not as something to be awarded in middle life after some of the most productive years have passed, but as something to be given to a young person who has mastered the basic knowledge and techniques of economics and who shows ability and promise, then the argument for the long period becomes much less persuasive. I lean strongly toward the latter concept of the degree.

It is against this background that we should look to the substantial increase in the economics graduate education in the postwar period in the US. In the case of the MIT program, the number of economics $\mathrm{PhDs}$ who graduated each year raised astronomically (see Svorencik this volume): if the average number in the $1940 \mathrm{~s}$ was 2.5 students per year, it went to 18.8 in the $1960 \mathrm{~s} .{ }^{18}$ This increase at MIT accompanied similar trends in other economics graduate programs such as Yale's (with an average of 3 students per year in the 1940s, and almost 12.6 in the 1960s), despite the fact that some of them were older and more established than MIT's. ${ }^{19}$ Even other new programs, as the one that Rochester

\footnotetext{
${ }^{17}$ Indeed, as Bowen $(1953,48)$ summarized, "we cannot hope to make every Ph.D. into a Wesley Mitchell or a J. M. Keynes. We can, however, insist that they know something about the basic methods of research in economics and that they are able to apply these methods in relatively limited research situations."

${ }^{18}$ The MIT department of economics explicitly stated in the MIT Bulletins of the early 1940s that a small group of graduate students will be admitted to the PhD program ("who can be given an individual type of instruction", MIT Bulletin 1944-45, p. 72), a language abandoned by 1946.

19 The data on Yale comes from the Yale Book of Numbers, 1701-1976 and 1976-2000, available at http://oir.yale.edu/17011976-yale-book-numbers (accessed on March 1, 2013). The data for 1976, missing in these books, was obtained from an archivist at Yale's Manuscripts and Archives, who consulted the Graduate School Report of the Dean.
} 
implemented after hiring Lionel McKenzie, were not much smaller than MIT's: in 1958 McKenzie reported that Rochester had 5 doctoral students (while MIT had 9), and that he expected to have 13 in 1959 (MIT had 18), and "add about five to eight students each year for the three years following 195960 " (MIT reached 19 students in 1963). ${ }^{20}$

As already indicated, there were very few universities who produced a substantial number of $\mathrm{PhDs}$ in the late 1940s and 1950s, which constituted a group of the ten big producers that awarded roughly sixty percent of all $\mathrm{PhD}$ degrees in economics. Among them, Harvard, Columbia, Chicago, and Wisconsin awarded almost forty percent of all PhD degrees, as reported by Bowen (1953, 209-10, 214):

Table 2

\begin{tabular}{|c|l|c|c|}
\hline Rank & Institution & $\begin{array}{c}\text { Percentage of } \\
\text { Ph.D.'s awarded } \\
\text { 1945-46 through } \\
1950-51\end{array}$ & $\begin{array}{c}\text { Number of } \\
\text { Ph.D.'s awarded } \\
\text { 1945-46 through } \\
1950-51\end{array}$ \\
\hline 1 & Harvard & 17,1 & 257 \\
2 & Columbia & 8,8 & 132 \\
3 & Chicago & 6,3 & 95 \\
4 & Wisconsin & 6,1 & 92 \\
5 & Cornell & 4,5 & 68 \\
6 & Illinois & 4,4 & 66 \\
7 & Minnesota & 3,2 & 48 \\
8 & Iowa & 3,1 & 46 \\
9 & New York & 3,1 & 46 \\
10 & Ohio State & $\underline{3,1}$ & 47 \\
& Total & 59,7 & 897 \\
\hline
\end{tabular}

Source: Bowen $(1953,209-10,214)$

In contrast to these top-10 institutions, MIT awarded only twenty one $\mathrm{PhDs}$ in the same years (1945-46 through 1950-51), which corresponded to only 1.4 percent of the economics PhDs awarded in the period (Bowen 1953, 210). The figures for Yale, Princeton, Northwestern, Duke, and Pittsburgh programs that existed at least since the mid-1920s -, according to Bowen, varied from 14 to $24 \mathrm{PhDs}$ awarded $(0.9 \%-1.6 \%) .{ }^{21}$ These institutions ranked higher than many others that awarded from 1 to 10 $\mathrm{PhDs}$ in these five years. So, despite of being a new program, the MIT doctorate in industrial economics managed to attract a good number of students from its inception.

In terms of the graduate courses in economics that MIT offered to its students in the early years (1940s and 1950s), all of them were elective It was not unusual then to have undergraduate and graduate students attending these courses at MIT and several other universities, an issue analyzed by Bowen (who emphasized the need to have separate courses dedicated to master's and to doctoral students). Looking at the courses listed as being "primarily for Graduate students" at the MIT Bulletin for the years of 1945 and 1955, we have the following list:

\footnotetext{
${ }^{20}$ Lionel McKenzie Papers, David M. Rubenstein Rare Book and Manuscript Library, Duke University. Box 7, folder “Outgoing Correspondence 1959”, July 15, 1959 letter to Thomas H. Carrol.

${ }^{21}$ Instead of the 24 students reported by Bowen for Yale, the Yale Book of Numbers registers 27 PhDs in this period.
} 
Table 3

\begin{tabular}{|c|c|c|c|c|c|}
\hline \multicolumn{3}{|c|}{$1945-46$} & \multicolumn{3}{|c|}{$1955-56$} \\
\hline No. & Subject & Instructor & No. & $\begin{array}{l}\text { Subject } \\
\end{array}$ & Instructor \\
\hline Ec17 & Economic Analysis & Samuelson & 14.116 & Econ. \& Financ. Pol. III & Adelman \\
\hline Ec18 & Economic Analysis & Samuelson & 14.121 & Economic Analysis & Bishop \\
\hline Ec19 & Math. Approach to Economics & Samuelson, H. A. Freeman & 14.122 & Economic Analysis & Samuelson \\
\hline Ec24 & Schools of Economic Thought & D. V. Brown, Bissell & 14.132 & Schools of Economic Thought & Bishop \\
\hline Ec26 & Business Cycles & Samuelson & 14.151 & Math. Approach to Econ. & Samuelson \\
\hline Ec37 & Econ. Statistics, Adv. & H. A. Freeman, Samuelson & 14.161 & Economic History & W. W. Rostow \\
\hline Ec47 & Investment Finance & D. S. Tucker & 14.162 & Economic History & W. W. Rostow \\
\hline Ec48 & Investment Analysis & D. S. Tucker & 14.171 & Economic Growth, Th. & Rosenstein-Rodan \\
\hline Ec59 & International Economics & R. E. Freeman & 14.172 & Res. Seminar in Econ. Develop. & Milikan \\
\hline Ec66 & Seminar in Indust. Rel. & Pigors & 14.174 & Non-Econ. Factors in Econ. Growth & Hagen \\
\hline Ec67 & Seminar in Labor Probs. & D. V. Brown & 14.191 & Economics Seminar & R. E. Freeman \\
\hline Ec68 & Seminar in Labor Probs. & D. V. Brown & 14.192 & Economics Seminar & R. E. Freeman \\
\hline Ec721 & Psych. Perception \& Action & Cartwright & 14.195 & Read. Sem. in Econ. & -- \\
\hline Ec735 & Group Psychology, Adv. & Bavelas & 14.196 & Read. Sem. in Econ. & -- \\
\hline Ec75 & Lab. In Research Methods & Lippitt & 14.271 & Industrial Econ., Prob. & Adelman \\
\hline Ec76 & Lab. In Research Methods & Lippitt & 14.272 & Gov. Regulation of Industry & Adelman \\
\hline Ec77 & Seminar in Topol. Psych. & Lewin & 14.281 & Econ. of Entrepren. \& Innova & Maclaurin \\
\hline Ec781 & Social Psych. of Change & Radke & 14.282 & Econ. of Innova. Sem. & Maclaurin \\
\hline Ec782 & Social Psych. of Change & Radke & 14.291 & Industrial Econ., Sem. & -- \\
\hline Ec791 & Psychological Seminar, Adv. & Lewin, Radke & 14.292 & Industrial Econ., Sem. & -- \\
\hline Ec792 & Psychological Seminar, Adv. & Lewin & 14.382 & Economic Statistics & Solow \\
\hline Ec793 & Psychological Seminar, Adv. & Lewin & 14.391 & Res. Seminar in Econ. & Solow \\
\hline Ec794 & Psychological Seminar, Adv. & Lewin & 14.451 & National Income & Milikan \\
\hline Ec82 & Govt. Control of Industry & Thresher & 14.461 & Monetary \& Banking Prob. & R. E. Freeman \\
\hline Ec91 & Economics Seminar & R. E. Freeman & 14.472 & Fiscal Policy & E. C. Brown \\
\hline Ec92 & Economics Seminar & R. E. Freeman & 14.481 & Business Cycles & Solow \\
\hline Ec93 & Ind. Econ. Seminar & D. V. Brown & 14.581 & International Economics & Kindleberger \\
\hline Ec94 & Ind. Econ. Seminar & D. V. Brown & 14.582 & International Economics & Kindleberger \\
\hline Ec95 & Social Science Seminar & McGregor & 14.671 & Prob. in Labor Econ. & Myers, Shultz \\
\hline Ec96 & Social Science Seminar & Knickerbocker & 14.672 & Public Pol. on Labor Rel. & -- \\
\hline & & & 14.673 & Labor-Manage. Rel. \& Publ. Pol. & D. V. Brown, Shultz \\
\hline & & & 14.681 & Personnel Admin., Sem. & Pigors \\
\hline & & & 14.682 & Personnel Admin., Sem. & Pigors \\
\hline & & & 14.691 & Res. Sem. in Indust. Rel. & Myers \\
\hline & & & 14.692 & Res. Sem. in Indust. Rel. & Myers \\
\hline & & & 14.693 & Collect. Bargaining \& Union-Manage. Coop. & Scanlon \\
\hline & & & 14.694 & Sem. in Union-Manage. Coop. & Scanlon \\
\hline & & & 14.772 & Indust. Sociology Sem. & Shepard \\
\hline & & & 14.774 & Soc. Psych. Sem. & Bavelas \\
\hline & & & 14.775 & Anal. of Behavior Sem. & Licklider \\
\hline & & & 14.776 & Anal. of Behavior Sem. & Licklider \\
\hline & & & 14.784 & Psychological Theory Sem. & Bavelas \\
\hline & & & 14.791 & Read. Sem. in Social Science & -- \\
\hline & & & 14.792 & Read. Sem. in Social Science & -- \\
\hline
\end{tabular}

One interesting aspect is that this list reflects the changes in the faculty body and the broad research interests indicated in the previous section. Together with an increase in the number of courses offered (from 30 in 1945 to 44 in 1955), the graduate program in industrial economics kept its identity. However, there was a relative reduction in psychology courses and an increase in economics courses, with new areas now covered, such as economic history, economic development, economic growth, economics of innovation, national income, money and banking, and fiscal policy.

In terms of formal requirements, the MIT graduate school specified four: one major field concluding with a general examination, one minor field in an area distinct from the major (with the idea that the minor would contribute to the development of professional leadership rather than improving technical competence), proficiency in two scientific modern foreign languages, and the thesis in the major field. From its inception the $\mathrm{PhD}$ program in industrial economics stated that students ought to have some understanding of all fields offered, which included economic theory. However, students would choose four fields to compose their major and their general examination - and here economic theory was not mandatory, but just one option among many. In 1948 the number of fields for the examination increased to six. In 1951 things changed: now students would be examined in five fields (with two or three designated as primary and requiring "more intensive preparation than the other two or three, which are designated as secondary"), but all of them must "demonstrate an elementary knowledge 
in Statistics and have taken one graduate subject in Economic History" (MIT Bulletin 1951, 107). This situation remained the same until 1957 when economic theory became compulsory to all students, who would be examined in five fields: economic theory was a required primary field to everybody and the same requirements for statistics and economic history applying as before.

After graduating, what were the job opportunities to the MIT economists? We will, once again, focus on the period 1944-1959 and try to identify the placement of the PhD students. In Table 4 below, we have the major advisors of this period, the number of students advised (counting to each professor only the students that he served as primary advisor), and the percentage of the students of each advisor whose placement information was available ("placement coverage"). Of those students whose placement was identifiable, I indicated the kind of placement they had: in the private sector, academia (not including business schools), in business schools, in the government and international agencies (IMF and United Nations), and in other sectors (research institutes, foundations, Cowles Commission, etc.). Interesting patterns are shown in Table 4:

\section{Table 4}

\begin{tabular}{|c|c|c|c|c|c|c|c|}
\hline \multirow[b]{2}{*}{ MIT Advisors } & \multirow[b]{2}{*}{$\begin{array}{l}\text { Number of } \\
\text { Advisees, } \\
1944-1959\end{array}$} & \multirow[b]{2}{*}{$\begin{array}{c}\text { Placement } \\
\text { Coverage (\%) }\end{array}$} & \multicolumn{5}{|c|}{ Placement Distribution } \\
\hline & & & $\begin{array}{l}\text { Private } \\
\text { Sector }\end{array}$ & $\begin{array}{c}\text { Academia (not } \\
\text { Business } \\
\text { School) }\end{array}$ & $\begin{array}{c}\text { Business } \\
\text { School }\end{array}$ & $\begin{array}{c}\text { Government } \\
\text { and It'l } \\
\text { Agencies }\end{array}$ & Other \\
\hline M. Adelman & 8 & 88 & 14,3 & 71,4 & 0,0 & 0,0 & 14,3 \\
\hline R. Bishop & 4 & 100 & 0,0 & 50,0 & 25,0 & 25,0 & 0,0 \\
\hline D. Brown & 14 & 86 & 50,0 & 16,7 & 16,7 & 8,3 & 8,3 \\
\hline W. Isard & 3 & 100 & 0,0 & 66,7 & 0,0 & 33,3 & 0,0 \\
\hline C. Kindleberger & 13 & 100 & 0,0 & 84,6 & 0,0 & 15,4 & 0,0 \\
\hline C. Myers & 19 & 89 & 5,9 & 64,7 & 23,5 & 5,9 & 0,0 \\
\hline P. Samuelson & 13 & 100 & 15,4 & 69,2 & 0,0 & 7,7 & 7,7 \\
\hline H. Sheppard & 6 & 67 & 0,0 & 75,0 & 0,0 & 0,0 & 25,0 \\
\hline R. Solow & 7 & 100 & 0,0 & 100,0 & 0,0 & 0,0 & 0,0 \\
\hline \multicolumn{8}{|l|}{ All Advisors } \\
\hline $1944-59$ & 107 & 88 & 12,8 & 62,8 & 10,6 & 7,4 & 6,4 \\
\hline 1944-49 & 15 & 87 & 30,8 & 38,5 & 7,7 & 7,7 & 15,4 \\
\hline $1950-59$ & 92 & 88 & 9,9 & 66,7 & 11,1 & 7,4 & 4,9 \\
\hline
\end{tabular}

One noteworthy characteristic is that for most advisors the majority of their students (whose placement information was available) went to academic positions. ${ }^{22}$ The exception was Douglass Brown, a professor of industrial relations, who had most of his students going to the private sector. The other professors whose some of their students went to the private sector were Morris Adelman and Charles Myers, both advising on industrial economics and business administration, and Paul Samuelson. To the business schools went students of the industrial relations professors, D. Brown and C. Myers, and of Robert Bishop. And six of the nine advisors listed had students going to governments and international agencies.

The overall placement pattern of MIT economists followed somewhat the employment trends of the time: Bowen $(1953,1)$ indicated that the majority of economists were employed in higher education, followed by the government and by the business sector. Jobs for economists with a $\mathrm{PhD}$ degree in the government had increased greatly in previous decades while the business sector hired only a very small, though steadily growing, share of economists. ${ }^{23}$ This is roughly the picture we get in the first row of the

\footnotetext{
${ }^{22}$ Walter Isard (Harvard PhD in economics, 1943), listed as an adviser, was first a research fellow and lecturer at Harvard (1943-1953), then a professor associated to the Center for Urban and Regional Studies that was part of the MIT School of Architecture. Isard advised thesis catalogued as from the economics department.

${ }^{23}$ Fourcade $(2009,110)$ presents data on economists employed in the government in the US and this number increased steadily from the mid-1950s to the early 1980 s.
} 
bottom section of Table 4 with all advisors, but with more MIT students going to the private sector than to the government as compared to the data showed by Bowen. When we look at all advisors in two subperiods, the 1940s and the 1950s, we see that the private sector was much more important in the first period, employing almost the same as academia. However, in the 1950s the importance of academic jobs skyrocketed while the private sector shrank to the level of the government (which stayed basically constant over these periods).

A few additional issues emerge when we look at placements of students of each of the major advisors. First, it was common to have students as instructors at the MIT economics department either prior to their thesis defense or immediately after graduation (case in which I also looked at their employment after this position). Second, several of the major advisors had at least one student who stayed at the MIT after graduation: C. Myers, D. Brown, H. Shepard, M. Adelman, and A. Bavelas. ${ }^{24}$ Third, three students, one advised by Max Millikan (who advised only two students in this period) and two by Robert Solow (out of his seven advisees), went to the MIT Center for International Studies.

In terms of institutions that hired MIT students more often, a few are worth mentioning: Rice Institute (one student advised by Kindleberger and two by Adelman), business schools (mostly Berkeley, but also Columbia, Chicago, University of Pennsylvania, Minnesota, Pittsburgh, and others), Minnesota and Northwestern (each hired three students, with two additional students going to the linguistic department and the transportation center at Northwestern), and Michigan State University (two students advised by C. Myers, plus one student of D. Brown whose second appointment was there). University of Michigan was also a place where MIT students went, even if also after their first appointment (with some of them going to the department of industrial relations), and University of Brandeis hired two students advised by Samuelson. RAND Corporation and Cowles each hired just one MIT economist in the period 1944-1959 (advised by Solow and Samuelson, respectively).

Given the small scale of the MIT program in the formative years, the number of students who went to particular sectors or institutions is significant. And the wide range of the job network for MIT economists is an interesting aspect of a graduate program that was on the rise.

\section{3 - Concluding Remarks}

As the social importance of economists in the US in the postwar period increased and as the American education expanded after the GI Bill, a new graduate training in economics started to take shape. There was an expansion of the existing programs and the creation of new ones, together with the reformulation of the nature of that training. Economists became increasingly seen as technicians who should go through core courses and show proficiency in techniques applied to narrowly defined problems. PhD degrees would be awarded to young people who would perfect their techniques in practice after graduation, and who were expected to write shorter and narrower theses.

The PhD program in industrial economics at MIT was part of the general expansion of graduate education. It originated from the need to give engineers and scientists an education in social sciences (Cherrier this volume). And the program found its way to face the changes in economics and economists' training of the time and it went through a substantial expansion in the first two decades, a pattern shared with some other universities. Both the number of students and of professors increased in

\footnotetext{
${ }^{24}$ Samuelson had one advisee whose second appointment was at MIT: Richard Eckaus, who graduated in 1954 and was associated to the Center for International Studies and its director in 1957, and who stayed at Brandeis University from 1951 to 1961, going to MIT in 1962. During his time at Brandeis, Eckaus received an offer from Rochester (thanks to Samuelson's recommendation to Lionel McKenzie) that he eventually declined (Lionel McKenzie Papers, David M. Rubenstein Rare Book and Manuscript Library, Duke University, Box 6, folders “1957 Letters at Mich., includes Debreu on eq. paper" - April 1, 1957 letter from Samuelson - and "Lionel W. McKenzie (incoming) Sept. 1957-Sept. 1958” - February 14, 1958 letter from Eckaus.
} 
the early years. Overall, the MIT economics program had close ties with Harvard, the biggest producer of PhDs at the time. The program kept its industrial relations identity but gradually emphasized the training in several fields of economics and reduced relatively the role played in it by psychology. In two periods the department offered a second $\mathrm{PhD}$ program: group psychology (1945-47) and political science (1958-65).

From the advisors' side, we see that not only Samuelson, but also Myers and Douglass Brown were very important in the first decade of a program with clear industrial relations identity. In the subsequent years other professors entered this group and started reshaping the program with a stronger economics identity: Kindleberger, Franklin Fisher, Solow, and Adelman. The first three, in turn, advised students who later became distinctive MIT advisors: Peter Temin, Jagdish Bhagwati, Peter Diamond, and Stanley Fischer.

Looking at the students, in addition to the courses they had available, we saw that their placement was wide, but clearly connected to the kind of work and advisors they had. The private sector absorbed more those students who worked in industrial economics and business administration (advised by D. Brown and Myers), and in industrial organization (Adelman). Business schools hired mostly students in industrial economics. Nonetheless, the majority of jobs that MIT students had were in universities, such as Rice Institute, Minnesota, Northwestern, and Michigan State University, among others.

Despite being new, the MIT PhD program managed to attract a good number of students from the beginning. In the early years, it was not among the major producers of economists with a $\mathrm{PhD}$ degree. But it was not alone in this situation: it had the good company of several other programs already well established, like Yale's, Princeton's, and Northwestern's, for example. The MIT program eventually managed to increase its relative importance in the production of doctorates in economics and became a leading institution contributing to the Americanization of economics.

\section{4 - Bibliography}

Barber, W. J. (1996). Postwar Changes in American Graduate Education in Economics. HOPE, 28(annual suppl.), 12-30.

Bowen, H. R. (1953). Graduate Education in Economics. American Economic Review, 43(4, part 2, suppl.), ii$\mathrm{xv}+1-223$.

Dixit, A. (2012). Paul Samuelson's Legacy. Annual Review of Economics, 4, 1-31.

Fourcade, M. (2009). Economists and Societies: discipline and profession in the United States, Britain, and France, 1890s to 1990s. Princeton: Princeton University Press.

Goodwin, C. (1975). Introduction. In C. Goodwin (Ed.), Exhortation and Controls: The Search for a Wage-Price Policy, 1945-1971 (pp. 1-8). Washington, D.C.: The Brookings Institution.

Mirowski, P. (2002). Machine Dreams: economics becomes a cyborg science. Cambridge: Cambridge University Press.

Morgan, M. S., \& Rutherford, M. (Eds.). (1998). From Interwar Pluralism to Postwar Neoclassicism (Annual Supplement to Vol. 30, HOPE ed.). Durham: Duke University Press.

Solberg, W. U., \& Tomilson, R. W. (1997). Academic McCarthyism and Keynesian Economics: The Bowen Controversy at the University of Illinois. HOPE, 29(1), 55-81.

Szenberg, M., Gottesman, A., \& Lall, R. (2005). Paul A. Samuelson: On Being an Economist. New York: Jorge Pinto Books.

Weintraub, E. R. (2002). How Economics Became a Mathematical Science. Durham: Duke University Press. 


\section{FIGURES}

Fig. 1

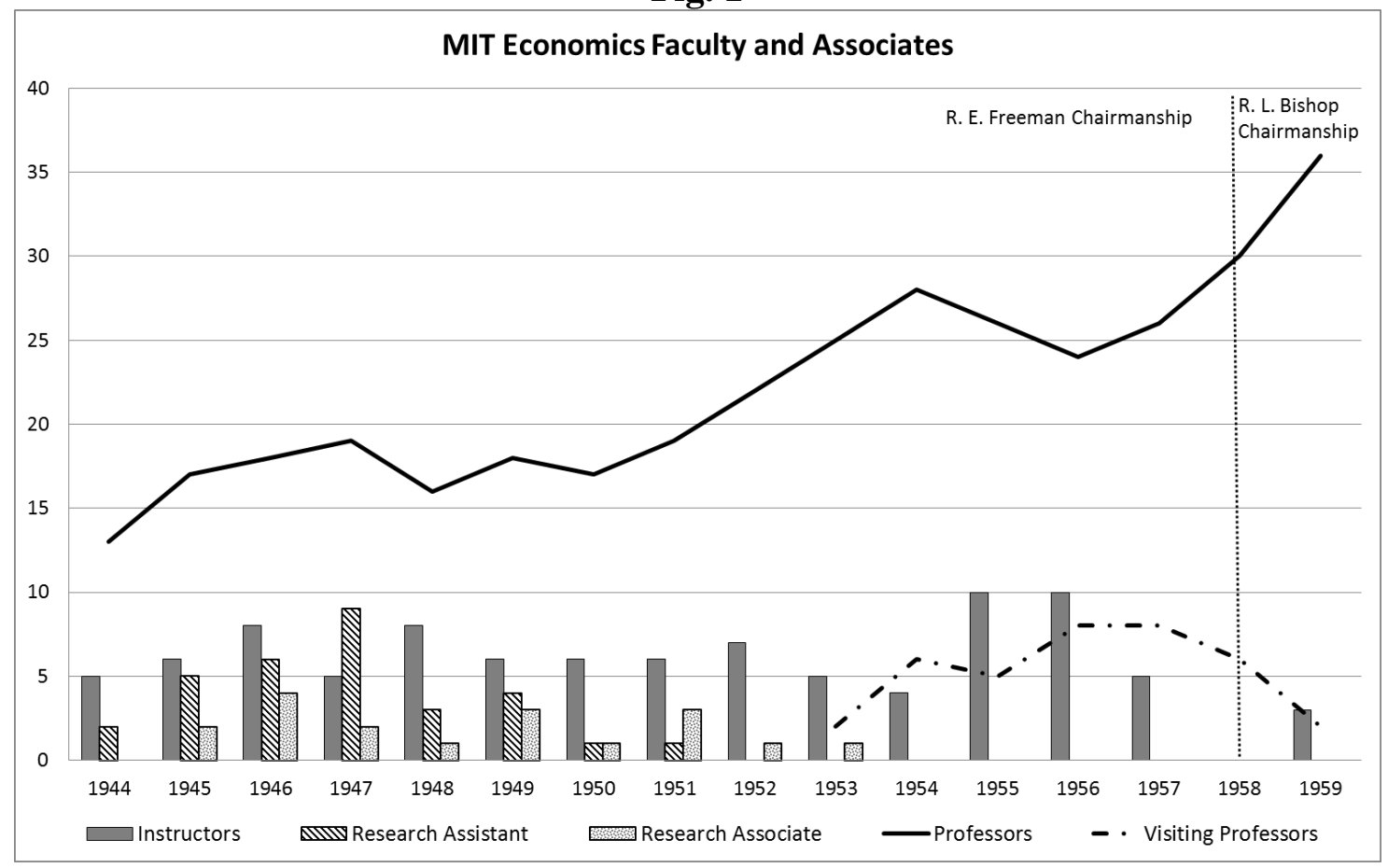

Fig. 2

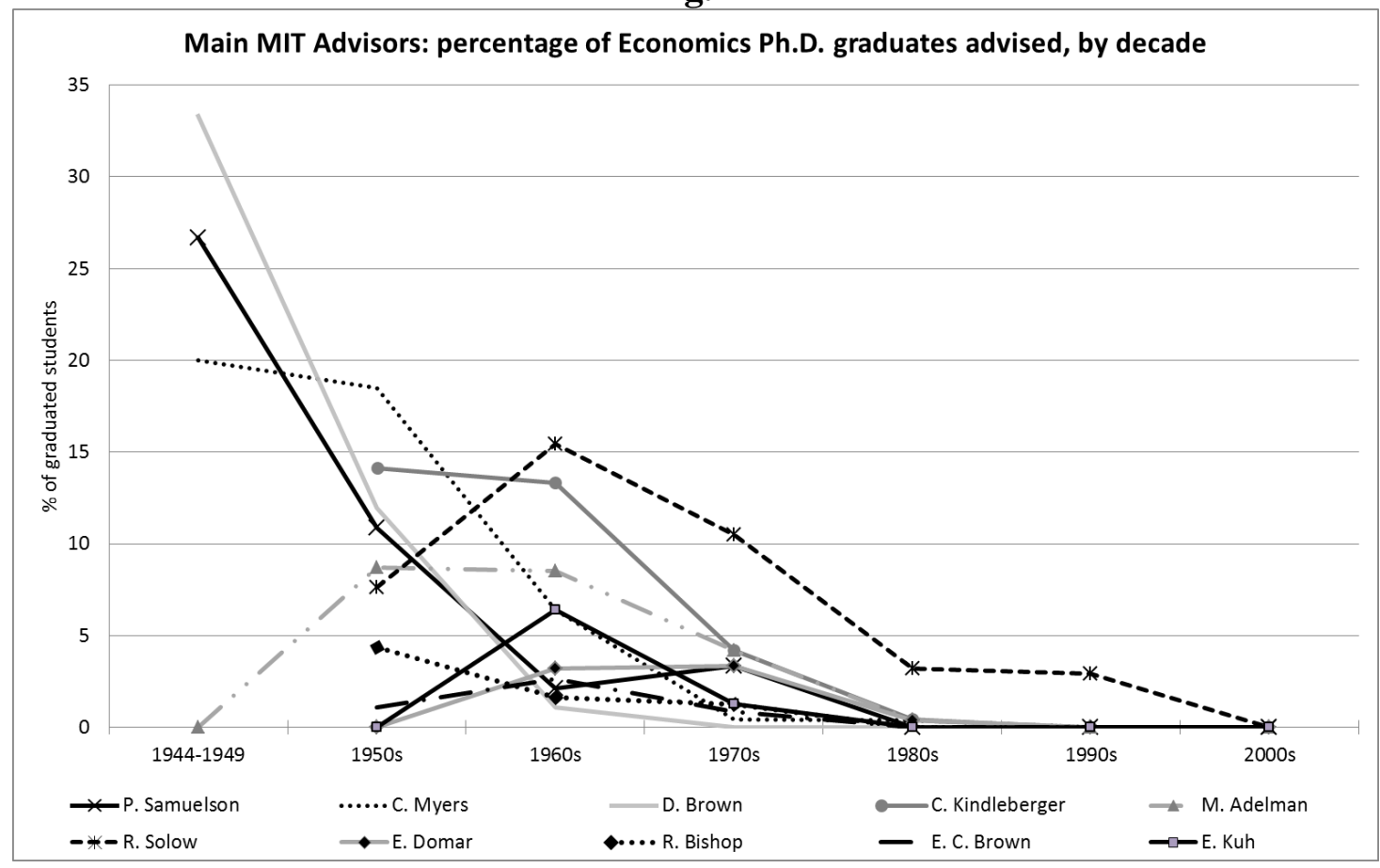


Fig. 3

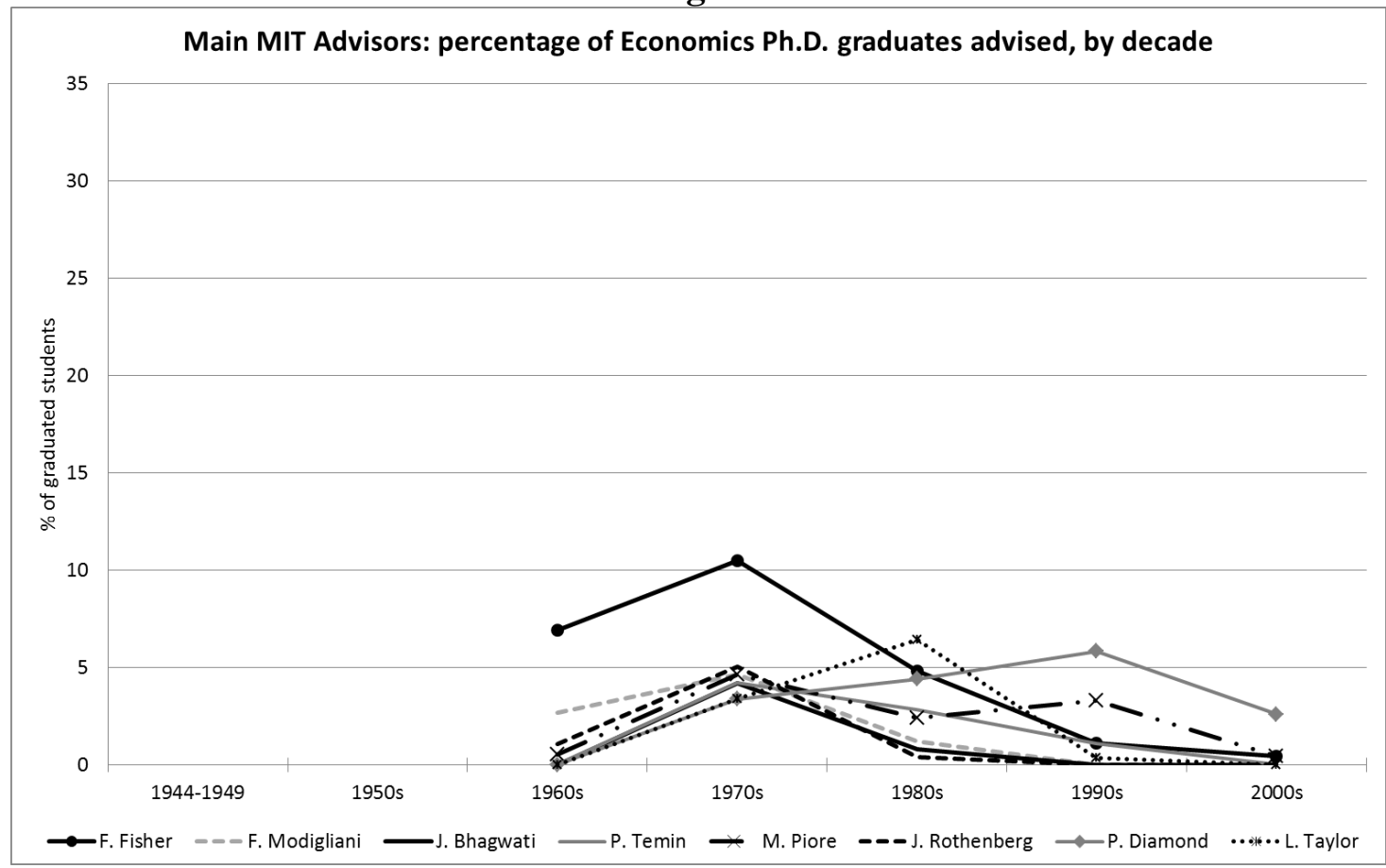

